\title{
Developing a Model for Controlling Internal Corrosion in Water Supply System
}

\author{
Byung-Gi Hwang \\ Department of Civil Engineering, Sangmyung University, Seoul, South Korea \\ Email: bh4abc@naver.com
}

How to cite this paper: Hwang, B.-G. (2017) Developing a Model for Controlling Internal Corrosion in Water Supply System. Journal of Water Resource and Protection, 9, 183-192.

https://doi.org/10.4236/jwarp.2017.92013

Received: December 14, 2016

Accepted: February 3, 2017

Published: February 6, 2017

Copyright $\odot 2017$ by author and Scientific Research Publishing Inc. This work is licensed under the Creative Commons Attribution International License (CC BY 4.0).

http://creativecommons.org/licenses/by/4.0/

\begin{abstract}
A model was developed to generate charts that fit the conditions as diverse temperatures and ionic strengths, and that estimate the diversified state of water. The chart can be used as a tool for controlling corrosive waters resulted in internal corrosion and the model producing charts composed of a number of sub modules, and each module incorporated parameters including acidity, alkalinity, $\mathrm{pH}$, and calcium ion. Utilizing the chart water quality of the raw water in $G$ water purification works was estimated to be unsaturated and Langelier index becomes -1.4 which means that the water is highly corrosive and calcium carbonate would not be precipitated. Thus, the water requires treatment as the injection of water stabilizing chemicals to promote an oversaturated (protective) condition. As a result of adding $5 \mathrm{mg} / \mathrm{L}$ of lime, it is possible to be precipitated with $5 \mathrm{mg} / \mathrm{L}$, and the water becomes noncorrosive. In addition, when $5 \mathrm{mg} / \mathrm{L}$ of caustic soda is added as a conditioning chemical, it signifies to be precipitated with $9 \mathrm{mg} / \mathrm{L}$, and the water also turns out to be largely noncorrosive. Both chemicals are possible to use for the water to be favorable for the formation of a protective film. Optimum injection rate for controlling corrosion can be found by repeating the procedures until the well-conditioned water criteria are satisfied.
\end{abstract}

\section{Keywords}

Model, Sub Module, Corrosive, Water Stabilization Chemicals, Langerlier Index

\section{Introduction}

Nevertheless for the last several decades aged water supply pipes and rust irresistible material pipes had been replaced for rust resistible pipes such as stainless pipe, PE pipe, and PVC pipe and also continuous effort including flushing pipes to supply a safe drinking water has been conducted, a number of the complaints have been continuously increased from drinking water users due to rust stains 
found in the pipes. One of the largest complaints for drinking water is caused by rust stains being generated by internal corrosion of water supply pipeline [1] [2].

In Korea, as the corrosiveness of water quality has increased due to the low alkalinity and hardness of raw water, and excessive quantities of injection of chlorine and coagulants in the process of water treatment [3] [4], it is required to introduce an effective water treatment method that can control the corrosive water.

Controlling internal corrosion in water service pipelines is to change the quality of raw water, which includes $\mathrm{pH}$ control and injection of corrosion inhibitor that is utilized in existing water purification facilities for controlling water quality [2] [5].

In order to control effectively the corrosive water quality, it is necessary not only to evaluate the quality of raw water accurately, but also to predict and estimate the changes in water quality in case of injection of calcium hydroxide, caustic soda, or soda ash to change the corrosive water into a noncorrosive water, provided that the raw water has been evaluated as having corrosive water qualities. Caldwell Lawrence chart [6] [7] [8] has been widely utilized in practice to achieve the goal, which is complicated in the procedures of use; and also, restricted charts are only available so that it does not reflect diversified water quality characteristics.

This study aimed to develop a model that can generate diversified charts conforming to the water quality characteristics and to make the program able to be processed simply and conveniently in practice by an operator, so that it would be a useful tool to help making decision for controlling water quality in water supply pipeline system.

\section{Study Contents and Methods}

\subsection{Overview}

The model developed in this study represents the correlations between alkalinity, acidity, $\mathrm{pH}$, and calcium with the coordinates of parameters of acidity and (alkalinity-calcium) in graph. The coordinate system is set up so that alkalinity minus calcium increases on the positive direction of horizontal axis, and acidity increases on the negative direction of vertical axis. In the $C 1$ and $C 2$ co-ordinate system $C 1$ is defined as negative Acidity and increases in the positive $Y$ direction. while the parameter $C 2$ increase in the positive $X$ direction as $C 1=-$ Acidity and $C 2=$ Alkalinity-calcium, where

$$
\text { Alkalinity }=\left[\mathrm{HCO}_{3}^{-}\right]+\left[\mathrm{CO}_{3}^{=}\right]+\left[\mathrm{OH}^{-}\right]-\left[\mathrm{H}^{+}\right]
$$

and

$$
\text { Acidity }=\left[\mathrm{HCO}_{3}^{*}\right]+\left[\mathrm{HCO}_{3}^{-}\right]+\left[\mathrm{H}^{+}\right]-\left[\mathrm{OH}^{-}\right] .
$$

\subsection{Model Setup}

Each of the parameters $\mathrm{pH}$, calcium (Ca) and Alkalinity (Alk) can be expressed in terms of the co-ordinate parameters as $\mathrm{pH}=F 1(C 1, \mathrm{C} 2), \mathrm{Alk}=F 2(C 1, C 2)$, 
and $\mathrm{Ca}=F 3(C 1, \mathrm{C} 2)$. Lines representing saturated equilibrium values for these parameters can be found by solving these equations and are plotted in the diagram. Choosing a series values for $C 1$ the corresponding values of $C 2$ for each expression can be found. Repeating this procedure for a number of $\mathrm{Ca}, \mathrm{Alk}, \mathrm{pH}$ values the diagram composed of a number of lines can be plotted. In the diagram, the intersection point of the lines representing the values of any two of these parameters defines the equilibrium value of the third parameter.

\section{Numerical Modeling}

Equations for plotting the parameters as alkalinity, $\mathrm{pH}$ and calcium were used to relate each of the parameters to the co-ordinate parameters $C 1$ and $C 2$. They are derived from equilibrium conditions for water conditioning from previous studies [9] [10] [11]. The model incorporating those equations are composed of several submodels: XLN_PH, computes pH lines; XLN_CA, generates calcium lines; YLN_ALKH, produces alkalinity horizontal lines; YLN_ALKV, determines alkalinity vertical lines; XY_PLOT, combines output files from the four submodels and plots lines. The engine used to develop the model is MATLAB, which is a computer program that provides the user with a convenient environment for performing many types of calculations and having graphical capabilities, and offers a tool to implement numerical methods. The model operating procedures are summarized in the flow chart shown in Figure 1.

\subsection{Submodel for $\mathrm{pH}$ Lines}

Equations were arranged for $\mathrm{HCO}_{3}^{-}$to determine $\mathrm{pH}$ lines as below:

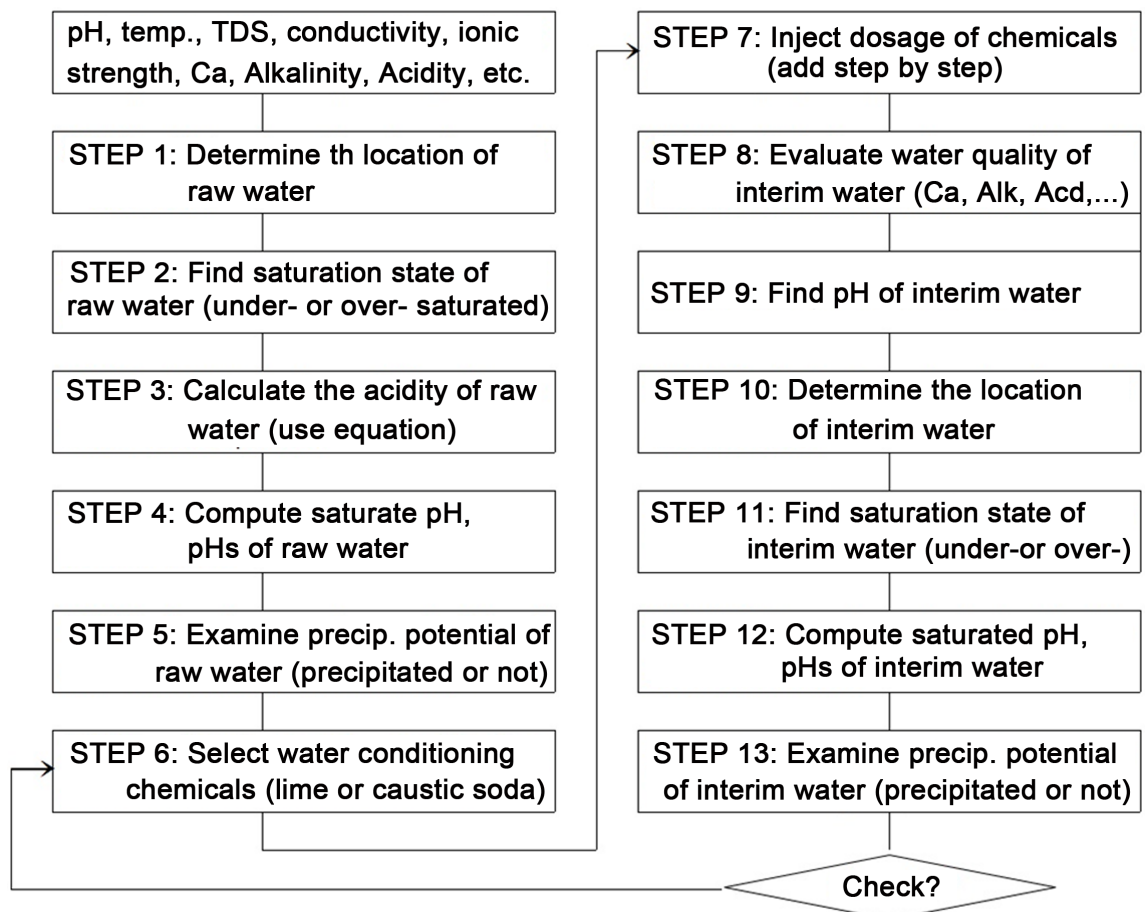

Figure 1. Flow chart for model operating procedures. 


$$
\begin{gathered}
\mathrm{C} 1=K_{c W}^{\prime} / \mathrm{H}^{+}-\mathrm{HCO}_{3}^{-}-\mathrm{H}^{+} \bullet \mathrm{HCO}_{3}^{-} / K_{c 1}^{\prime}-\mathrm{H}^{+} \\
\left(-1-K_{c 2}^{\prime} / \mathrm{H}^{+}\right)\left[\mathrm{HCO}_{3}^{-}\right]^{2}+\left(C 2-K_{c W}^{\prime} / \mathrm{H}^{+}+\mathrm{H}^{+}\right)\left[\mathrm{HCO}_{3}^{-}\right]+K_{c S}^{\prime} \bullet \mathrm{H}^{+} / K_{c 2}^{\prime}=0
\end{gathered}
$$

where:

$$
\begin{aligned}
& \frac{\left[\mathrm{H}^{+}\right]\left[\mathrm{HCO}_{3}^{-}\right]}{\left[\mathrm{H}_{2} \mathrm{CO}_{3}^{*}\right]}=\frac{K_{1}}{f_{m}^{2}}=K_{1}^{\prime} ; \frac{\left[\mathrm{H}^{+}\right]\left[\mathrm{CO}_{3}^{=}\right]}{\left[\mathrm{HCO}_{3}^{-}\right]}=\frac{K_{2}}{f_{d}}=K_{2}^{\prime} ; \\
& {\left[\mathrm{H}^{+}\right]\left[\mathrm{OH}^{-}\right]=\frac{K_{w}}{f_{m}^{2}}=K_{W}^{\prime} ;\left[\mathrm{Ca}^{++}\right]\left[\mathrm{CO}_{3}^{=}\right]=\frac{K_{s}}{f_{d}^{2}}=K_{s}^{\prime}}
\end{aligned}
$$

where $K_{1}=$ first dissociation constant for carbonic system; $K_{2}=$ second dissociation constant for carbonic acid; $K_{w}=$ dissociation constant for water; $K_{S}$ $=$ solubility product constant for carbonic system.

The fundamental equilibria equations for the calcium-carbonic system can be written with species concentrations expressed in ppm as $\mathrm{CaCO}_{3}$ by modifying the equilibrium constants as follows:

$$
K_{1}^{\prime} \times 2.5 \times 10^{4}=K_{c 1}^{\prime} ; \quad K_{2}^{\prime} \times 10^{5}=K_{c 2}^{\prime} ; \quad K_{1}^{\prime} \times 10^{10}=K_{c S}^{\prime} ; \quad K_{w}^{\prime} \times 25 \times 10^{8}=K_{c W}^{\prime}
$$

It is difficult to solve Equations (1) and (2) directly so that numerical integrating should be adopted. The value of $\mathrm{HCO}_{3}^{-}$can be found while changing C2 with a constant interval for one fixed value of $\mathrm{H}^{+}$, and then the obtained value substituted into equation of $\mathrm{C} 1$ to obtain one line for $\mathrm{pH}$. It is possible to obtain multi lines conforming to the fixed values of $\mathrm{H}^{+}$in diverse range.

\subsection{Submodel for Ca Lines}

Equations were arranged for $\mathrm{HCO}_{3}^{-}$to determine calcium lines as below:

$$
\begin{aligned}
\mathrm{C} 2=\mathrm{HCO}_{3}^{-} & +K_{c S}^{\prime} / \mathrm{Ca}^{++}+\frac{K_{c W}^{\prime} \bullet K_{c S}^{\prime}}{\mathrm{HCO}_{3}^{-} \bullet K_{c 2}^{\prime} \bullet \mathrm{Ca}^{++}}-\mathrm{Ca}^{++}-\mathrm{HCO}_{3}^{-} \bullet K_{c 2}^{\prime} \bullet \mathrm{Ca}^{++} \\
& \frac{K_{c 2}^{\prime} \bullet \mathrm{Ca}^{++}}{K_{c S}^{\prime} \bullet K_{c 1}^{\prime}}\left[\mathrm{HCO}_{3}^{-}\right]^{3}+\left(1+\frac{K_{c 2}^{\prime} \bullet \mathrm{Ca}^{++}}{K_{c S}^{\prime}}\right)\left[\mathrm{HCO}_{3}^{-}\right]^{2} \\
& +C 1\left[\mathrm{HCO}_{3}^{-}\right]-\frac{K_{c W}^{\prime} \bullet K_{c S}^{\prime}}{K_{c 2}^{\prime} \bullet \mathrm{Ca}^{++}}=0
\end{aligned}
$$

Laguerre method and Muller method [12] [13] can be utilized for obtaining a multinomial solution. The solution generates three roots, incorporating with 1 real root and 2 conjugation imaginary roots from the characteristics of correlation equation. In case of substituting the real root in the equation, one line is obtained for the fixed value of $\mathrm{Ca}^{++}$. Further changing the value of $\mathrm{Ca}^{++}$for 2 , 5,10 and then from 20 to 100 , the corresponding lines are produced.

\subsection{Submodel for Alkalinity Lines}

Alkalinity lines plot in the diagram as curves each with two horizontal limbs joined by a vertical section of curve. To plot the horizontal section of curve, for some chosen Alkalinity $C 1$ values are calculated for corresponding $C 2$ values. For the vertical section of curve $C 2$ values are calculated for corresponding $C 1$ 
values. An alkalinity line becomes a curve by adding up two horizontal lines and one perpendicular line.

1) Alkalinity horizontal lines

To obtain the horizontal line for alkalinity, equations were arranged for $\mathrm{H}^{+}$ and could be expressed as:

$$
\begin{gathered}
C 1=K_{c W}^{\prime} / \mathrm{H}^{+}-\left[\mathrm{H}^{+}\right]^{2} \bullet X / K_{c 1}^{\prime} \bullet K_{c 2}^{\prime}-\mathrm{H}^{+} \bullet X / K_{c 2}^{\prime}-\mathrm{H}^{+} \\
\left(\frac{K_{c S}^{\prime}}{K_{c 2}^{\prime}\left(\mathrm{Alk}-C_{2}\right)}-1\right)\left[\mathrm{H}^{+}\right]^{2}-\left(\frac{K_{c S}^{\prime}}{\mathrm{Alk}-C_{2}}-\mathrm{Alk}\right) \bullet \mathrm{H}^{+}+K_{c W}^{\prime}=0
\end{gathered}
$$

where $X=K_{c S}^{\prime} /(\mathrm{Alk}-C 2)$. Pursuant to the characteristics of equation, two real roots were obtained, one of those is a negative root that draws the horizontal line on the lower part and the other draws the horizontal line on the upper part, respectively. Each of the lines produces regions where a value is suddenly increased larger than a constant horizontal value before connecting to the perpendicular line. At this stage, the angle was restricted to less than $45^{\circ}$, an angle being increased more than the angle $45^{\circ}$ was prohibited by treating to generate an error [7].

It is designed to obtain the value of $C 1$ while increasing the value of $C 2$ with a constant interval within the range for the fixed value of alkalinity. When connecting a series of obtained $C 1$ and $C 2$ coordinate values each together, one line is found, and further corresponding lines are explored while changing the value of alkalinity in wide range.

$$
\begin{aligned}
C 1= & \frac{K_{c W}^{\prime}\left(\mathrm{Alk}-\mathrm{HCO}_{3}^{-}\right)}{K_{c 2}^{\prime} \bullet \mathrm{HCO}_{3}^{-}+K_{c W}^{\prime}}+\frac{\mathrm{HCO}_{3}^{-}\left(K_{c 2}^{\prime} \bullet \mathrm{HCO}_{3}^{-}+K_{c W}^{\prime}\right)}{K_{c 1}^{\prime}\left(\mathrm{Alk}-\mathrm{HCO}_{3}^{-}\right)} \\
& +\mathrm{HCO}_{3}^{-}+\frac{K_{c 2}^{\prime} \bullet \mathrm{HCO}_{3}^{-}+K_{c W}^{\prime}}{\mathrm{Alk}-\mathrm{HCO}_{3}^{-}} \\
& C 2-\mathrm{Alk}-\frac{K_{c S}^{\prime}}{K_{c 2}^{\prime} \bullet \mathrm{HCO}_{3}^{-}} \bullet \frac{K_{c 2}^{\prime} \bullet \mathrm{HCO}_{3}^{-}+K_{c W}^{\prime}}{\mathrm{Alk}-\mathrm{HCO}_{3}^{-}}=0
\end{aligned}
$$

The solution was found by integrating the equations and could be classified into two categories: in one case three roots were all real ones, the smallest value was used; in other case roots including an imaginary root were found, the smallest value was used among the value of real number of a complex root and real roots. The value of $\mathrm{HCO}_{3}^{-}$was obtained while increasing the value of $C 1$ for the fixed value of alkalinity with a constant interval; $C 2$ was determined by substituting the value in Equations (7) and (8), and then one alkalinity line was found, and in addition corresponding lines are produced while changing the value of alkalinity in diverse range.

\section{Results and Discussion}

The physical and chemical characteristics of the raw water sampled from $G$ water purification facility of Nakdong River water system are shown in Table 1. The current state of water quality was evaluated step by step by utilizing the 
Table 1. Results of water quality changes by injection of water conditioning chemicals.

\begin{tabular}{|c|c|c|c|}
\hline \multirow{2}{*}{$\begin{array}{l}\text { Physical and chemical } \\
\text { parameters }\end{array}$} & \multirow{2}{*}{$\begin{array}{c}\text { Raw } \\
\text { water }\end{array}$} & \multicolumn{2}{|c|}{ Chemicals added } \\
\hline & & $\mathrm{Ca}(\mathrm{OH})_{2}$ & $\mathrm{NaOH}$ \\
\hline Physical properties & \multicolumn{3}{|c|}{$T=25 \mathrm{C} ; \mathrm{TDS}=40 \mathrm{mg} / \mathrm{L} ; I=0.001$} \\
\hline $\mathrm{pH}$ & 7.2 & 9.0 & 9.0 \\
\hline Calcium mg/L as $\mathrm{CaCO}_{3}$ & 40 & 45 & 40 \\
\hline Alkalinity $\mathrm{mg} / \mathrm{L}$ as $\mathrm{CaCO}_{3}$ & 42 & 47 & 47 \\
\hline Acidity $\mathrm{mg} / \mathrm{L}$ as $\mathrm{CaCO}_{3}$ & 47 & 42 & 42 \\
\hline $\mathrm{C} 2 \mathrm{mg} / \mathrm{L}$ as $\mathrm{CaCO}_{3}$ & 2 & 2 & 7 \\
\hline $\mathrm{pH}_{\mathrm{s}}$ & 8.60 & 8.45 & 8.50 \\
\hline Saturation state & under & over & over \\
\hline$[\mathrm{Ca}]_{\mathrm{sat}} \mathrm{mg} / \mathrm{L}$ as $\mathrm{CaCO}_{3}$ & - & 40 & 36 \\
\hline $\mathrm{CaCO}_{3}$ precip. potential & -4 & 5 & 9 \\
\hline Langelier's index & -1.4 & 0.55 & 0.50 \\
\hline
\end{tabular}

chart developed in this study, and the results are summarized in the table. In order to evaluate the state of raw water, the chart corresponding to temperature $25^{\circ} \mathrm{C}$, and ionic strength, $I=0.001$ was selected. The lines corresponding to alkalinity $42 \mathrm{mg} / \mathrm{L}$ (as $\mathrm{CaCO}_{3}$ ), calcium $40 \mathrm{mg} / \mathrm{L}$ (as $\mathrm{CaCO}_{3}$ ), $\mathrm{pH} 7.2$ from the chart were connected, and let the intersections as $A, B$, and $C$, and then it was represented by the three-sided envelope $A B C$ as shown in Figure 2, which represents that the water is not saturated, since the three lines do not meet at a single point.

Because the raw water is not saturated from the results of step 1 , the value of calcium concentration was read out from the calcium line, passing the intersection between the alkalinity line and the $\mathrm{pH}$ line in order to determine whether it is over-saturated or under-saturated; this became $[\mathrm{Ca}]_{\text {sat }}=90 \mathrm{mg} / \mathrm{L}$ as a saturated calcium concentration, and because the value exceeded the measured calcium concentration $[\mathrm{Ca}]_{i}=40 \mathrm{mg} / \mathrm{L}$, it signifies that the raw water becomes under-saturated. Hence, the water requires treatment to promote an oversaturated (protective) condition.

The acidity of the raw water was obtained from the value of $Y$-axis where it met the horizontally extended line at the intersection between the alkalinity line and the $\mathrm{pH}$ line, and the acidity was $47 \mathrm{mg} / \mathrm{L}$. In cases of low calcium concentration and low concentration of alkalinity, because the intersection between the calcium line and the alkalinity line is located outside the left boundaries of the chart, it is not able to calculate the acidity. In such a case, it could calculate the acidity directly by utilizing the equations suggested from previous studies [9] [10] [11].

The saturated $\mathrm{pH}$ concentration, $\mathrm{pH}_{s} 8.6$ was obtained by reading out the $\mathrm{pH}$ value at the intersection of the calcium and alkalinity lines. Langelier Saturation Index [8] [14], LSI of -1.4 was obtained by utilizing the parameter, signifying that the water is corrosive. 
TEMPERATURE $=25.0^{\circ} \mathrm{C}$ IONIC STRENGTH $=0.001$

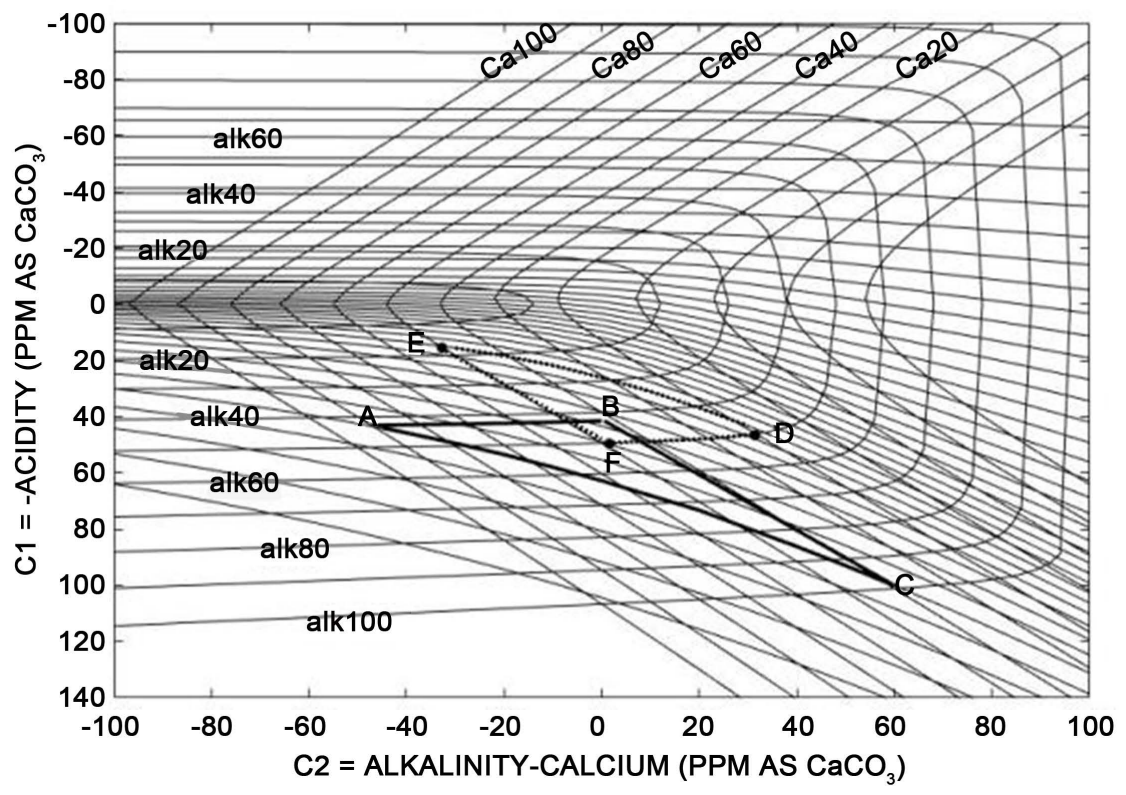

Figure 2. Evaluation process of water quality changes due to addition of water stabilizers.

The saturated calcium concentration $[\mathrm{Ca}]_{\text {sat }}$ was obtained by reading out the calcium value at intersection $F$, where the extended line of acidity and the vertical line from point $B$ were met. A potential quantity of calcium carbonate precipitation (CCPP) was obtained from subtraction of the saturated calcium concentration and the measured calcium concentration, which CCPP was -4 , signifying that the water is under-saturated or corrosive.

The corrosion evaluation indexes resulting from steps 4 and 5 expressed that the raw water was corrosive. A chemical product injected to change the noncorrosive water to the corrosive water is called water quality stabilizer, for which calcium hydroxide or sodium hydroxide is widely used. The procedures to evaluate changes of water quality according to an injection of water quality stabilizer are examined in the following sections.

The procedures to change corrosive water into noncorrosive water while increasing the concentration of calcium hydroxide by $5 \mathrm{mg} / \mathrm{L}$ and $10 \mathrm{mg} / \mathrm{L}$ as a water quality stabilizer are summarized in the following, and the results are listed in Table 1.

In cases where the raw water is under-saturated, it is necessary to change the water to a saturated state by injecting conditioning chemicals. As a result of adding calcium hydroxide $5 \mathrm{mg} / \mathrm{L}$, the calcium concentration becomes $46 \mathrm{mg} / \mathrm{L}$ by increasing $5 \mathrm{mg} / \mathrm{L}$. At that time, the hydroxyl ion $\left(\mathrm{OH}^{-}\right)$concentration is increased by $5 \mathrm{mg} / \mathrm{L}$, so that alkalinity $\left(=\left[\mathrm{HCO}_{3}^{-}\right]+\left[\mathrm{CO}_{3}^{=}\right]+\left[\mathrm{OH}^{-}\right]-\left[\mathrm{H}^{+}\right]\right)$becomes $47 \mathrm{mg} / \mathrm{L}$ by increasing $5 \mathrm{mg} / \mathrm{L}$. The increase of hydroxyl ion concentration caused to decrease the acidity $\left(=\left[\mathrm{HCO}_{3}^{*}\right]+\left[\mathrm{HCO}_{3}^{-}\right]+\left[\mathrm{H}^{+}\right]-\left[\mathrm{OH}^{-}\right]\right)$by 5 $\mathrm{mg} / \mathrm{L}$, and then the acidity becomes $42 \mathrm{mg} / \mathrm{L}$.

The pHof the interim water is found according to change of injection amounts. In Figure 2, after addition of water quality stabilizer, the $\mathrm{pH}$ read 9.0 at the in- 
tersection where it met with the value of the alkalinity line $(47 \mathrm{mg} / \mathrm{L})$ by extending the acidity line $(42 \mathrm{mg} / \mathrm{L})$. When the calcium line $(45 \mathrm{mg} / \mathrm{L})$, the alkalinity line $(47 \mathrm{mg} / \mathrm{L})$, and the $\mathrm{pH}$ line $(\mathrm{pH}=9.0)$ were connected, the envelope enclosed by DEF is formed, signifying that the interim water is in an unsaturated state.

As the concentration of the calcium line $(15 \mathrm{mg} / \mathrm{L})$ passing through the intersection $D$ between the alkalinity line and the $\mathrm{pH}$ line is lower than the calcium concentration of the interim water $45 \mathrm{mg} / \mathrm{L}$, the interim water is over-saturated and precipitation can occur. The saturated $\mathrm{pH}$ read as 8.45 at the intersection between the alkalinity line and calcium line of the interim water for the saturated state. LSI of 0.55 was obtained by estimating the index. Since the index is positive, the water is in noncorrosive state. The area enclosed by dotted lines DEF becomes reduced and collected to the point $F$. The point is the intersection between the (alkalinity-calcium) line $(1 \mathrm{mg} / \mathrm{L})$ and the acidity line $(42 \mathrm{mg} / \mathrm{L})$, signifying the saturated calcium concentration is $40 \mathrm{mg} / \mathrm{L}$. A possible precipitation amount is obtained by subtracting the saturated calcium concentration and the calcium concentration of the interim water $(45 \mathrm{mg} / \mathrm{L})$, so that $5 \mathrm{mg} / \mathrm{L}$ of precipitation can occur. Changes of water quality were evaluated by repeating the procedures step 9 through step 13 until the saturation state is slightly oversaturated, which means Langelier index is nearly zero or potential precipitation is about zero.

Sodium hydroxide $5 \mathrm{mg} / \mathrm{L}$ was injected as a water quality stabilizer, and increased or decreased amounts of calcium, alkalinity, and acidity of the treated water was estimated due to the injection. As the calcium concentration is not increased, so it comes out at $41 \mathrm{mg} / \mathrm{L}$. The concentration of hydroxyl ion $\left(\mathrm{OH}^{-}\right)$is increased by $5 \mathrm{mg} / \mathrm{L}$, so that the alkalinity becomes $47 \mathrm{mg} / \mathrm{L}$ by increasing 5 $\mathrm{mg} / \mathrm{L}$.

The acidity line $(42 \mathrm{mg} / \mathrm{L})$ was extended to obtain the $\mathrm{pH}$ of processing water corresponding to changes of injection amount, and then the $\mathrm{pH}$ of 9.0 was read at intersection between the extended acidity line $(42 \mathrm{mg} / \mathrm{L})$ and the alkalinity line $(47 \mathrm{mg} / \mathrm{L})$. When the calcium line $(45 \mathrm{mg} / \mathrm{L})$, the alkalinity line $(47 \mathrm{mg} / \mathrm{L})$, and the $\mathrm{pH} 9.0$ line were connected, an envelope enclosed by three-sided lines was formed, signifying that the treated water is in an under-saturated state.

Because the concentration of the calcium line $(15 \mathrm{mg} / \mathrm{L})$ passing through the intersection between the alkalinity line and the $\mathrm{pH}$ line in step 11 is lower than the calcium concentration of the interim water $(45 \mathrm{mg} / \mathrm{L})$, the interim water is in a supersaturated state, therefore signifying the possibility to be precipitated.

The saturated $\mathrm{pH}$ of 8.5 was obtained by reading out the $\mathrm{pH}$ value at the intersection between alkalinity line and the calcium line of the interim water for the saturated state. LSI of 0.50 was obtained by estimating the Langlier Index. The index is positive, signifying a corrosive water quality. In step 13 , the area surrounded by the dotted lines became reduced and collected to point $\mathrm{F}$, which is the intersection between the alkalinity minus calcium line $(1 \mathrm{mg} / \mathrm{L})$ and the acidity line $(42 \mathrm{mg} / \mathrm{L})$, signifying a saturated calcium concentration is $36 \mathrm{mg} / \mathrm{L}$. 
The possible precipitation amount was found by subtracting the saturated calcium concentration $(36 \mathrm{mg} / \mathrm{L})$ and the calcium concentration $(45 \mathrm{mg} / \mathrm{L})$, and 9 $\mathrm{mg} / \mathrm{L}$ of precipitation can occur.

\section{Conclusions}

The model that can generate charts conforming to combinations of temperatures and ionic strengths has been developed to control corrosive waters. The results using the model are summarized as follows:

Water quality of the raw water that collected in sampling station was evaluated, with the results showing that it is in an unsaturated state because LSI was -1.4 and possible precipitation amount of calcium carbonate was $-4 \mathrm{mg} / \mathrm{L}$, signifying corrosive water. $5 \mathrm{mg} / \mathrm{L}$ of calcium hydroxide as a water conditioning chemical was injected as an effort to convert corrosive waters to non-corrosive waters, and changes of water quality were estimated. As a result, Langelier index of the treated water turns out to be LSI of 0.55 and possible precipitation amount of calcium carbonate is $5 \mathrm{mg} / \mathrm{L}$, which signifies noncorrosive water. When 10 $\mathrm{mg} / \mathrm{L}$ of calcium hydroxide is injected, it may generate calcium carbonate precipitation of $14 \mathrm{mg} / \mathrm{L}$ which exceeds the minimum possible amount of precipitation; therefore it has been judged by us that the more injection will not be needed.

In case of injection of sodium hydroxide $5 \mathrm{mg} / \mathrm{L}$, the $\mathrm{pH}$ was estimated at 9.0 and the saturated $\mathrm{pH}$ was 8.5. LSI of 0.50 and possible precipitation amount of calcium carbonate was $9 \mathrm{mg} / \mathrm{L}$, which means non-corrosive. The saturated calcium concentration was $36 \mathrm{mg} / \mathrm{L}$ and the calcium concentration of the treated water $46 \mathrm{mg} / \mathrm{L}$, so that it signifies to be precipitated. Therefore the model developed in this study could serve as a useful tool controlling corrosive waters in practice by an operator.

\section{Acknowledgements}

This study was supported by 2011 Academic Research Fund of Sangmyung University, and partially supported by 2015 Construction Technology Region Specialization Project Fund of the Ministry of Land, Infrastructure and Transport.

\section{References}

[1] Lim, J.C., Kim, J.K. and Koo, J.Y. (2012) Coating Formation of Water Supply Pipes by Inhibitor and Water Quality Improvement Effect. Journal of the Korean Society of Water and Wastewater, 26, 97-106. https://doi.org/10.11001/jksww.2012.26.1.097

[2] Woo, D.S. and Hwang, B.G. (2014) Corrosivity Evaluation of SWRO Membrane Desalted Permeate. Journal of the Korean Society of Civil Engineers, 18, 53-59. https://doi.org/10.1007/s12205-014-0161-7

[3] Lee, D.J., Kim, Y.I. and Park, H.A. (2008) Corrosion Control in Water Distribution System Using Lime and Carbon Dioxide. Journal of the Korean Society of Water and Wastewater, 22, 379-388.

[4] Woo, D.S. and Hwang, B.G. (2008) A Study on the Corrosion Characteristics of 
Carbon Steel Pipes by Phosphate Corrosion Inhibitor. Journal of the Korea Academia-Industrial Cooperation, 9, 493-499. https://doi.org/10.5762/KAIS.2008.9.2.493

[5] Hwang, B.G. (2014) Determination of an Optimum Injection Rate Using Calcium Carbon Saturation Indices for Internal Corrosion Control in Distribution Water Pipe. Journal of the Korean Society of Water Treatment, 22, 11-18.

[6] Caldwell, D.H. and Lawrence, W.B. (1953) Water Softening and Conditioning Problems. Industrial \& Engineering Chemistry, 45, 535-548. https://doi.org/10.1021/ie50519a027

[7] Loewenthal, R.E. and Marais, G.R. (1976) Carbonate Chemistry of Aquatic Systems, Vol. I: Theory and Application. Ann Arbor, Michigan.

[8] Rossum, J.R. and Merrill, D.T. (1983) An Evaluation of the Calcium Carbonate Saturation Indexes. $A W W A, 75,95-100$.

[9] Murrill, D.T. and Sanks, R.L. (1977) Corrosion Control by Deposition of $\mathrm{CaCO}_{3}$ Films: Part 1. A Practical Approach for Plant Operators. AWWA, 69, 592-599.

[10] Murrill, D.T. and Sanks, R.L. (1977) Corrosion Control by Deposition of $\mathrm{CaCO}_{3}$ Films: Part 2. A Practical Approach for Operators. $A W W A, 69,634-640$.

[11] Murrill, D.T. and Sanks, R.L. (1978) Corrosion Control by Deposition of $\mathrm{CaCO}_{3}$ Films: Part 3. A Practical Approach for Plant Operators. $A W W A, 70,12-18$.

[12] Chapra, S.C. (2012) Applied Numerical Methods with MATLAB for Engineers and Scientists. McGraw Hill.

[13] Press, W.H., Teukolsky, S.A., Vetterling, W.T. and Flannery, B.P. (1997) Numerical Recipes in Fortran 77. Cambridge University Press, Cambridge.

[14] Langelier, W.F. (1936) The Analytical Control of Anti-Corrosion Water Treatment. $A W W A, 28,1500$.

Submit or recommend next manuscript to SCIRP and we will provide best service for you:

Accepting pre-submission inquiries through Email, Facebook, LinkedIn, Twitter, etc. A wide selection of journals (inclusive of 9 subjects, more than 200 journals)

Providing 24-hour high-quality service

User-friendly online submission system

Fair and swift peer-review system

Efficient typesetting and proofreading procedure

Display of the result of downloads and visits, as well as the number of cited articles

Maximum dissemination of your research work

Submit your manuscript at: http://papersubmission.scirp.org/

Or contact jwarp@scirp.org 